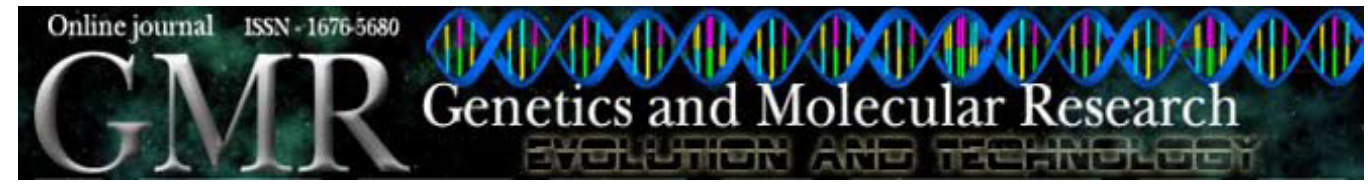

\title{
Evidence for the main foot protein gene in Perna perna (Mollusca, Mytilidae)
}

\author{
C. Clezar ${ }^{1}$, L.I. Weber ${ }^{1,2}$, G.S. Malaquias ${ }^{1}$ and P.O. Silva ${ }^{1}$ \\ ${ }^{1}$ Laboratório de Genética Molecular, CTTMar, \\ Universidade do Vale do Itajaí, Itajaí, SC, Brasil \\ ${ }^{2}$ Departamento de Genética, NUPEM/UFRJ, \\ Universidade Federal do Rio de Janeiro, Macaé, RJ, Brasil \\ Corresponding author: L.I. Weber \\ E-mail: liweber@nupem.ufrj.br
}

Genet. Mol. Res. 7 (2): 567-572 (2008)

Received April 2, 2008

Accepted June 10, 2008

Published June 24, 2008

\begin{abstract}
Here, we investigated the gene that encodes the main protein component of the byssus in Perna perna (Ppfp) using a consensus fluorescent probe for the Mytilus group and by polymerase chain reaction amplification using specific and random primers. A 524-bp fragment resulting from polymerase chain reaction amplification was found to be homologous to the $f p-1$ gene of Mytilus coruscus. This fragment was identified as the 3' end of the Ppfp-1 gene, which included the heptapeptide coding sequence for Lys-Pro-Ser-Tyr-Pro-Pro-Ter (probably the incomplete last tandem repeat unit of the giant exon), the stop codon and the polyadenylation signal.
\end{abstract}

Key words: Perna perna; Byssus; Foot proteins; $f p-1$ gene;

Polyphenolic protein 


\section{INTRODUCTION}

Proteins that compose the byssus in Mytilidae have high biotechnological value due to their unique properties of elasticity, resistance, and adhesion underwater. Currently, four polyphenolic proteins have been identified in Mytilidae. These polyphenolic proteins are secreted and stored by glands present in the foot of the mussels, and they contain some DOPA residues (Waite, 1997). The main component of the byssus is the fp- 1 protein $(110-130 \mathrm{kDa})$, which contains 70 to 80 tandem repeats in the last giant exon. These tandem repeats encode for decapeptides rich in hydroxylated tyrosine (DOPA: 3,4 hydroxyphenyl-L-alanine) and proline (Waite, 1983, 1997; Floriolli et al., 2000) residues. Most marine mussels contain the consensus decapeptide Ala-Lys-Pro*-Ser-Tyr*-Pro**Pro*-Tyr*(DOPA)-Lys, where $\mathrm{P} *$ represents $20 \%$ of trans-4-hydroxy-L-proline and $\mathrm{P} * *$ represents $10 \%$ of trans-2,3-cis-3,4-dihydroxyproline. DOPA, which is commonly represented twice in each repeated unit, corresponds to the redox functional group 3,4-dihydroxyphenyl-L-alanine. The catechol functionality of this group is thought to be responsible for adhesion and cross-linking of the proteins, in which the mechanisms are unknown (Yu et al., 1999). Therefore, fp-1 protein constitutes an important model for synthetic polymers, especially in the medical material industry (Warner and Waite, 1999). The sequence of the $f p-1$ gene in Mytilus edulis is known and has been used for a variety of biotechnological purposes. No studies have investigated these proteins and their respective genes in Perna perna, the most abundant Mytilidae of the Brazilian coast. Therefore, the aim of this study was to find the sequence of the $f p-1$ gene (Ppfp-1) in Perna perna.

\section{MATERIAL AND METHODS}

The following two strategies were used for the search of the main foot protein gene $(f p-1)$ in P. perna: 1) Southern blotting and hybridization using a fluorescent degenerate consensus probe (5'-ATA(T/A)GTTGGAGGATAA(G/C)TTGGCTT-3') specific for the Mytilus group designed from known sequences of the $M$. galloprovincialis $f p$ - 1 gene (Inoue and Odo, 1994), and 2) Specific primers previously described for the polymerase chain reaction (PCR) amplification of the Mytilus group $f p-1$ gene as well as random primers.

Twenty samples of P. perna were collected from the rocky shores of Praia Vermelha ( $\left.26^{\circ} 48^{\prime} \mathrm{S} ; 48^{\circ} 35^{\prime} \mathrm{W}\right)$, Santa Catarina, in the south of Brazil. DNA was extracted from the adductor muscle tissue following a modified phenol/chloroform extraction protocol (Hoelzel, 1998). At the most, $100 \mathrm{ng}$ of high quality DNA was extracted.

To have sufficient DNA for Southern blotting and hybridization $(50 \mu \mathrm{g})$, five independent isolations of DNA were carried out with each sample. Next, DNA was cut with HindIII and AluI restriction enzymes according to manufacturer instructions. Cleaved DNA was subjected to unidirectional capillary Southern blotting using a Hybond- $N^{+}$(Amersham Biosciences) membrane at neutral $\mathrm{pH}$, as described previously (Darling and Brickell, 1994). Hybridization was performed using a fluorescein-labeled probe, and the membrane was treated according to the protocol published by Sambrook and Russel (2001). Non-radioactive detection of hybridization was performed by the Gene Images ECL detection kit (Amersham Biosciences), which utilizes a chromogenic substrate. The membrane was incubated with anti-fluorescein antibodies conjugated to alkaline phosphatase. Two different substrates were used: naphthol AS phosphate/fast blue BB and BCIP/NTB (5-bromo-4-chloro-3-indolyl-phosphate/nitroblue-tetrazolium), according to previously published reports (Anderson, 1999). X-ray film was then exposed to the membrane for $1 \mathrm{~h}$ in the dark. Next, the film 
was developed for $1 \mathrm{~min}$ in developing solution, then bathed with 7\% acetic acid, and finally subjected to a fixing solution for $2 \mathrm{~min}$. Lastly, the film was assessed for the presence of hybrids.

Specific primers tested in $P$. perna correspond to those described for different species of the Mytilus group (Table 1). PCR amplification was performed in a total reaction volume of $25 \mu \mathrm{L}$ containing: 1X PCR buffer, $3.75 \mu \mathrm{L}$ BSA $(10 \mathrm{mg} / \mathrm{mL}), 2.0 \mu \mathrm{L} \mathrm{MgCl}_{2}(50 \mathrm{mM}), 0.24 \mu \mathrm{L}$ dNTPs $(100 \mathrm{mM}), 0.1 \mu \mathrm{L}$ each primer $(100 \mu \mathrm{M}), 0.3 \mu \mathrm{L}$ Taq polymerase $(10 \mathrm{U} / \mu \mathrm{L})$, and $10-40 \mathrm{ng}$ of DNA template. The reaction was then subjected to an initial 3-min cycle at $95^{\circ} \mathrm{C}$, followed by 44 cycles of $1 \mathrm{~min}$ at $94^{\circ} \mathrm{C}, 1 \mathrm{~min}$ at the minimum annealing temperature for the combination of primers listed in Table 1 , and $1 \mathrm{~min}$ at $72^{\circ} \mathrm{C}$, followed by a final 10 -min elongation step at $72^{\circ} \mathrm{C}$. All possible combinations of specific primers from Table 1, and all the combinations with the random primers of 10 nt (P1 to P6 from Amersham Pharmacia and OPA1 to OPA5, OPA7 to OPA9, OPA12, and OPA14 from the Operon Life Technologies) were made. PCR conditions were held constant with the exception of the annealing temperature, which was set at $40^{\circ} \mathrm{C}$ when amplification was performed with random primers. PCR amplicons obtained in high concentration and persisting after increasing the annealing temperature, as well as those present after combinations of specific-random primers but absent when amplification was performed with only random primers, were selected for sequence analysis (Macrogen, Korea) following purification (Ultrafree-DA, Millipore).

\begin{tabular}{|c|c|c|c|}
\hline Primer name & Sequence $5^{\prime}-3$ ' & Primer annealing region at the $f p-1$ & Reference \\
\hline \multicolumn{4}{|l|}{ Forward } \\
\hline F1 & $\begin{array}{l}\text { cctttcggtttatatggtgecggat } \\
\mathrm{AT}=66^{\circ} \mathrm{C}\end{array}$ & $\begin{array}{l}\text { Non-identified region at the } 5 \text { ' end of the coding } \\
\text { region of the } f p-1 \text { gene of Mytilus galloprovincialis }\end{array}$ & (1) \\
\hline $\mathrm{P} 1$ & $\begin{array}{l}\text { gcaaagccaacttataaa } \\
\mathrm{AT}=43^{\circ} \mathrm{C}\end{array}$ & $\begin{array}{l}\text { Consensus hexapeptide coding repeat unit } \\
\text { of the giant exon of the } f p-1 \text { gene in the } M \text {. edulis }\end{array}$ & (2) \\
\hline $\mathrm{P} 2$ & $\begin{array}{l}\text { atcctccaacttataaa } \\
\mathrm{AT}=42^{\circ} \mathrm{C}\end{array}$ & $\begin{array}{l}\text { Distal portion of the consensus decapeptide } \\
\text { coding repeat unit of the giant } \\
\text { exon of the } f p-1 \text { gene in the } M \text {. edulis }\end{array}$ & (2) \\
\hline JH5 & $\begin{array}{l}\text { gtaggaacaaagcatgaacca } \\
\mathrm{AT}=52^{\circ} \mathrm{C}\end{array}$ & $\begin{array}{l}\text { Region at the } 5 \text { ' end of the } 2.5-\mathrm{kb} \text { giant exon } \\
\text { of the } f p-1 \text { gene from } M \text {. edulis } \\
\text { and } M . \text { galloprovincialis }\end{array}$ & (3) \\
\hline PR8 & $\begin{array}{l}\text { aagccaagttatcctccaac } \\
\mathrm{AT}=53^{\circ} \mathrm{C}\end{array}$ & $\begin{array}{l}\text { Decapeptide coding repeat unit } \\
\text { number } 77 \text { of the giant exon of the } f p-1 \text { gene } \\
\text { of } M . \text { edulis and the corresponding } \\
\text { repeat in } M \text {. galloprovincialis }\end{array}$ & (3) \\
\hline $\mathrm{Me}-13$ & $\begin{array}{l}\text { ccacttgcaaagaagctgtcatct } \\
\mathrm{AT}=56^{\circ} \mathrm{C}\end{array}$ & $\begin{array}{l}\text { Conserved region of the giant exon } \\
\text { of the } f p-1 \text { gene }\end{array}$ & (4) \\
\hline $\mathrm{Me}-15$ & $\begin{array}{l}\text { ccagtatacaaacctgtgaaga } \\
\mathrm{AT}=56^{\circ} \mathrm{C}\end{array}$ & $\begin{array}{l}\text { Conserved region of the giant exon } \\
\text { of the } f p-1 \text { gene }\end{array}$ & (4) \\
\hline \multicolumn{4}{|l|}{ Reverse } \\
\hline R1 & $\begin{array}{l}\text { atgcttggatccgtatggatgtgaacc } \\
\mathrm{AT}=70^{\circ} \mathrm{C}\end{array}$ & $\begin{array}{l}\text { Non-identified region at the } 3 \text { ' end } \\
\text { of the } f p-1 \text { gene of } M \text {. galloprovincialis }\end{array}$ & (1) \\
\hline JH4 & $\begin{array}{l}\text { ctttcaaatgttcatctgttcctc } \\
\mathrm{AT}=58^{\circ} \mathrm{C}\end{array}$ & $\begin{array}{l}\text { The 3' untranslated end of the } f p \text { - } 1 \text { gene } \\
\text { from } M \text {. edulis and } M \text {. galloprovincialis }\end{array}$ & (3) \\
\hline JH54 & $\begin{array}{l}\text { ggggggataagttttcttagg } \\
\mathrm{AT}=56^{\circ} \mathrm{C}\end{array}$ & $\begin{array}{l}\text { The } 3 \text { ' end of coding region of the giant exon } \\
\text { of the } f p-1 \text { gene from } M \text {. edulis and } \\
\text { M. galloprovincialis }\end{array}$ & (3) \\
\hline Me-14 & $\begin{array}{l}\text { acaaacgttaaaatgtgtagtacagta } \\
\mathrm{AT}=56^{\circ} \mathrm{C}\end{array}$ & $\begin{array}{l}3 \text { ' end of the repetitive region of the } \\
\text { giant exon of the } f p-1 \text { gene }\end{array}$ & (4) \\
\hline Me-16 & $\begin{array}{l}\text { tgttgtcttattaggtttgtaaga } \\
\mathrm{AT}=56^{\circ} \mathrm{C}\end{array}$ & $\begin{array}{l}3 \text { ' end of the conserved region } \\
\text { of the giant exon of the } f p \text { - } 1 \text { gene }\end{array}$ & (4) \\
\hline
\end{tabular}

(1) Inoue et al., 1996; (2) Filpula et al., 1990; (3) Rawson et al., 1996; (4) Inoue et al., 1995.

AT $=$ annealing temperature. 


\section{RESULTS AND DISCUSSION}

No hybrids were obtained following Southern blotting and hybridization. The transfer of DNA to the membrane was successful, but no hybrids were obtained, suggesting that the probe was not complementary to the region of the $f p-1$ in $P$. perna.

Combinations of the specific primers Me-13/Me-16, Me-13/Me14, Me-15/Me16, and Me-15/Me14 did not amplify any fragments. Other combinations showed fragments, from which 40 were sent for sequencing, although only one showed similarity with the $f p-1$ of $M$. coruscus. This 524-bp fragment (GenBank Accession Number EU563923) was amplified using the forward PR8 primer (Filpula et al., 1990), which was designed from the 77th repetition unit of the giant exon of the $f p-1$ of $M$. edulis, and the reverse primer (R1) described by Inoue et al. (1996) designed from the $f p-1$ gene of $M$. galloprovincialis (Table 1). The amplicon was successfully aligned with the $M$. coruscus fp-1 gene (GenBank Accession Number D63777) (Inoue et al., 1996) at many places due to the similarity of the 5 ' end of the fragment found in P. perna with the M. coruscus 4th, 16th, 18th, 21st, 25th, 28th, 34th, 36th, 39th, 43rd, 49th, 53rd, 63rd, and 72nd repetition units. Nonetheless, the presence of a stop codon, followed by a possible polyadenylation site suggests that the fragment corresponds to the last portion of the gene (3' end). The final, but probably incomplete, repetition unit encodes for a heptapeptide repeat unit of the giant exon of the $f p-1$ gene in P. perna. The probable polyadenylation signal is consistent with the position of this signal in M. coruscus when the alignment begins at the 72nd repetition unit of $M$. coruscus (Figure 1). Although the possible polyadenylation signal has been shown to be an unconventional hexamer (AAUUAA), Beaudoing et al. (2000) demonstrated that polyadenylation signals are not strictly conserved when they observed a high proportion of alternative hexamers.

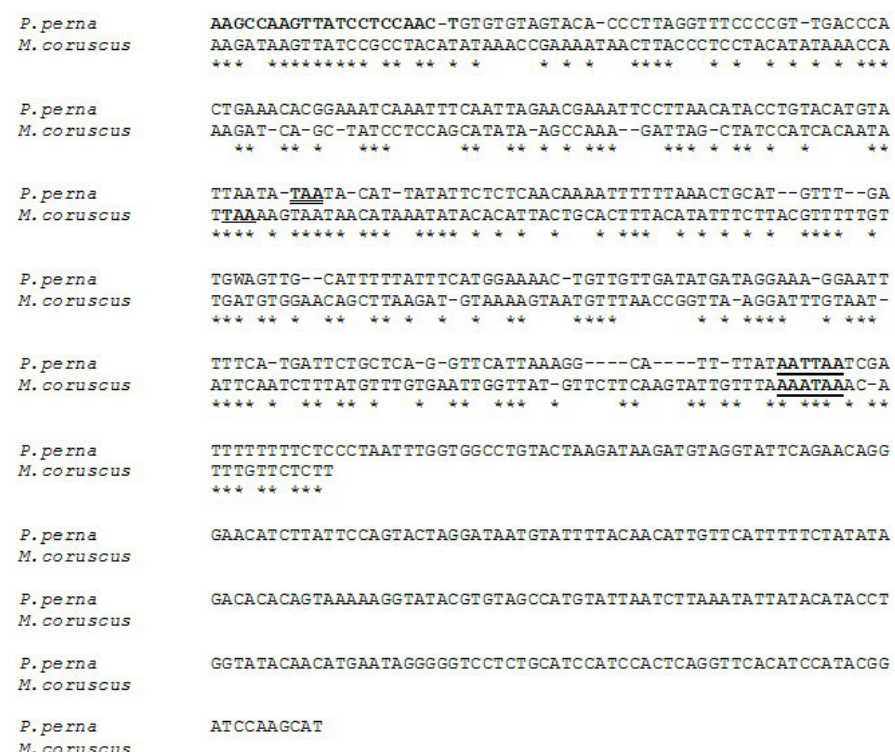

Figure 1. Alignment of the Perna perna sequence obtained with the terminal portion of the $f p$-1 gene of Mytilus coruscus. The last repetition unit found in P. perna (bold), the stop codon (bold and double underlined), and the most probable polyadenylation signal in P. perna, consistent with the position of this signal in M. coruscus (bold and single underlined) are shown. 
The translated portion $\left(\mathrm{KP} * \mathrm{SY} \mathbf{P}^{*} \mathrm{P}^{*} \mathrm{~T}\right)$ at the 5 ' end of the amplicon fragment in P. perna (Figure 2) is, in fact, part of the consensus repeat unit of most Mytilidae, where $\mathrm{P}^{*}$ corresponds to trans-4-hydroxy-L-proline, $\mathrm{P} * *$ represents trans-2,3-cis-3,4-dihydroxyproline, and $\mathrm{Y}^{*}$ (DOPA) represents the redox functional group 3,4-dihydroxyphenyl-L-alanine (Waite, 1983, 1997), which are all hydroxylated residues.

\section{$\begin{array}{llllllllllllllllllll}K & P^{*} & S & Y^{*} & P^{*} & P^{*} & \mathbf{T} & V & C & S & T & P & L & G & F & P & V & D & P & L\end{array}$}

1 AAGCCAAGTTATCCTCCAACTGTGTGTAGTACACCCTTAGGTTTCCCCGTTGACCCACTG

$$
\begin{array}{lllllllllllllllllllll}
K & H & G & N & Q & I & S & I & R & T & K & F & L & N & I & P & V & H & V & L
\end{array}
$$

61 AAACACGGAAATCAAATTTCAATTAGAACGAAATTCCTTAACATACCTGTACATGTATTA

I $S T O P$

121 ATATAATACATTATATTCTCTCAACAAAATTTTTTAAACTGCATGTTTGAT GNAGTTGCA

181 TTTTTATTTCATGGAAAACTGTTGTTGATATGATAGGAAAGGAATTTTTCATGATTCTGC

241 TCAGGTTCATTAAAGGCATTTTATAATTAATCGATTTTTTTTCTCCCTAATTTGGTGGCC

301 TGtACTAAGATAAGATGTAGGTATTCAGAACAGGGAACATCTTATTCCAGTACTAGGATA

361 ATGTATTTTACAACATTGTTCATTTTTCTATATAGACACACAGTAAAAAGGTATACGTGT

421 AgCCATGTATTAATCTTAAATATTATACATACCTGGTATACAACATGAATAGGGGGTCCT

\section{CTGCATCCATCCACTCAGGTTCACATCCATACGGATCCAAGCAT}

Figure 2. Full sequence found in Perna perna, showing the last incomplete repeat unit (bold) of the Ppfp- 1 last giant exon, the translated region in the top, the heptapeptide KPSYPPT (bold and underlined), where asterisks represent residues that are normally hydroxylated in the foot proteins, the stop codon (bold and double underlined), and the polyadenylation signal (bold and underlined).

No similarity was found with the repeat units of $P$. viridis (Ohkawa et al., 2004) and P. canaliculus (Zhao and Waite, 2005), which demonstrated significant differences with the Mytilus group and also between each other. Our results show that $P$. perna is more similar to the repetition units of the Mytilus group than to its congenerics. Although the last repeat unit found in P. perna may be an incomplete unit, we cannot rule out the possibility of the heptapeptide rule in P. perna. Other species have shown smaller repetition units than the characteristic decapeptide observed in the Mytilus group. Examples include the heptapeptide in Aulacomya ater (Burzio et al., 2000) and the tetrapeptide in P. canaliculus (Zhao and Waite, 2005).

After checking similarities in GenBank, we observed that part of the fragment found is very similar to a small region of the acetyl-CoA gene of many species. Nonetheless, this similarity was observed in the anti-sense strand, and our fragment is divided into two by another sequence in the acetyl-CoA gene, suggesting that there may be only an evolutionary relationship between the two genes. 


\section{ACKNOWLEDGMENTS}

We are very grateful to CNPq for financial support (\#479553/2004-1) and for Pro-BIC and PIPG/UNIVALI for grants given to P.O. Silva and C. Clezar, respectively.

\section{REFERENCES}

Anderson MLM (1999). Nucleic Acid Hybridization. Springer, New York.

Beaudoing E, Freier S, Wyatt JR, Claverie JM, et al. (2000). Patterns of variant polyadenylation signal usage in human genes. Genome Res. 10: 1001-1010.

Burzio LA, Saez C, Pardo J, Waite JH, et al. (2000). The adhesive protein of Choromytilus chorus (Molina, 1782) and Aulacomya ater (Molina, 1782): a proline-rich and a glycine-rich polyphenolic protein. Biochim. Biophys. Acta 1479: 315-320.

Darling DC and Brickell PM (1994). The Basic. Nucleic Acid Blotting. Oxford University Press, New York, 45-60.

Filpula DR, Lee SM, Link RP, Strausberg SL, et al. (1990). Structural and functional repetition in a marine mussel adhesive protein. Biotechnol. Prog. 6: 171-177.

Floriolli RY, von Langen J and Waite JH (2000). Marine surfaces and the expression of specific byssal adhesive protein variants in Mytilus. Mar. Biotechnol. 2: 352-363.

Hoelzel AR (1998). Molecular Genetic Analysis of Populations, a Practical Approach. Oxford University Press, Oxford.

Inoue K and Odo S (1994). The adhesive protein cDNA of Mytilus galloprovincialis encodes decapeptide repeats but no hexapeptide motif. Biol. Bull. 186: 349-355.

Inoue K, Waite JH, Matsuoka M, Odo S, et al. (1995). Interspecific variations in adhesive protein sequences of Mytilus edulis, M. galloprovincialis, and M. trossulus. Biol. Bull. 189: 370-375.

Inoue K, Takeuchi Y, Miki D, Odo S, et al. (1996). Cloning, sequencing and sites of expression of genes for the hydroxyargininecontaining adhesive-plaque protein of the mussel Mytilus galloprovincialis. Eur. J. Biochem. 239: 172-176.

Ohkawa K, Nishida A, Yamamoto H and Waite JH (2004). A glycosylated byssal precursor protein from the green mussel Perna viridis with modified dopa side-chains. Biofouling 20: 101-115.

Rawson PD, Joyner KL, Meetze K and Hilbish TJ (1996). Evidence for intragenic recombination within a novel genetic marker that distinguishes mussels in the Mytilus edulis species complex. Heredity 77 (Pt 6): 599-607.

Sambrook J and Russel DW (2001). Molecular Cloning. A Laboratory Manual. Cold Spring Harbor Laboratory Press, New York.

Waite J (1983). Adhesion in byssally attached bivalves. Biol. Rev. 58: 209-231.

Waite JH (1997). Marine bioadhesion: unraveling the biochemistry. J. Adhes. Soc. Jpn. 33: 18-22.

Warner SC and Waite JH (1999). Expression of multiple forms of an adhesive plaque protein in an individual mussel, Mytilus edulis. Mar. Biol. 134: 729-734.

Yu M, Hwang J and Deming TJ (1999). Role of L-3,4-dihydroxyphenylalanine in mussel adhesive proteins. J. Am. Chem. Soc. 121: 5825-5826.

Zhao H and Waite JH (2005). Coating proteins: Structure and cross-linking in fp-1 from the green shell mussel Perna canaliculus. Biochemistry 44: 15915-15923. 